\title{
The Diminishing Importance of Fate and Divine Femininity During the High and Late Roman Empire
}

\author{
PAUL LINJAMAA \\ Lund University
}

\begin{abstract}
Weaving and femininity are historically intimately connected with the concept of Fate. In antiquity Fate was portrayed as a powerful female principle controlling the cosmic system humans inhabited. However, as the antique religious world gave way to a new era, the role of Fate subsided under Christian dominance. This article examines how this change played out, and how the worldview that won prominence as Christianity prevailed gradually lost touch with the presence of powerful female cosmic principles. It shows that the disappearance of Fate from the prevailing world was seminal in the birth of a new 'technology of the self'. In conclusion, the article places the disappearance of Fate in the context of a discussion of how the view of the self changed in the aftermath of Christianity, which had become dominant. This discussion is related to the scholarship of Peter Brown, among others, as well as a newly published posthumous work by Michel Foucault (2018).
\end{abstract}

Keywords: Fate, technology of self, Michel Foucault, free will, femininity

The idea of Fate as a powerful female cosmic principle has been present as far back as we can see into the religious world of the Mediterranean basin (Eidinow 2011; DeConick 2011; Christ 1997). A popular portrayal of Fate was as a figure weaving and spinning the life thread of humanity, a task intimately associated with femaleness. ${ }^{1}$ When Christianity finally took

1 Homer depicted Penelope as weaving her father-in-law's funeral shroud and unweaving it every night to postpone her promise to remarry when the work was done: the weaving was connected with Odysseus's life. There are other myths: Ariadne, the daughter of Minos of Crete, managed the Labyrinth where Theseus fought the Minotaur. With her spun thread she guided Theseus in the labyrinth, saving his life. Ovid tells of Philomena who, by weaving a loom depicting the crime committed against her, thus sealed the Fate of her assailants (Metamorphoses VI, 575-87). Arachne, the most skilful of all spinners, was turned into a spider and sentenced to weave for all time when she insulted Zeus and failed to recognize that her skills came from Athena.

This work is licensed under a Creative Commons Attribution 4.0 International License. 
over as the only sanctioned religion in the Roman Empire - an empire in decline but still in control of much of the Mediterranean world - things had changed. The importance of Fate - and thus a powerful female cosmic principle - had subsided and ultimately disappeared. This article outlines the steps in which Fate's slow disappearance occurred between the high and late Roman Empire, ${ }^{2}$ and traces it to the birth of a new morality and view of selfhood.

The article is divided into four parts. First, a short contextualization is offered into the image and function of Fate in classical antiquity. Second, the early Christian receptions of Fate as a powerful feminine deity are analysed. It is argued that these receptions took two very specific forms: one affirming the importance of powerful images of female deities; the other rejecting them. The third part of the article begins to explore the reasons the versions of Christianity that would prevail in the theological struggles of the first centuries rejected Fate and divine femininity. The article ends by reading the disappearance of Fate in light of prominent scholars' views of the changes occurring in relation to the view of the self in the period of the high and late Roman Empire. It will be argued that a 'technology of the self', which Michel Foucault and other scholars have imagined, is introduced with the rise and prominence of Christianity, and that it is made possible in part by the disappearance of Fate.

\section{Turning the cosmic spindle: fate and femaleness}

In Graeco-Roman culture Fate came in many shapes, for example, Ananke

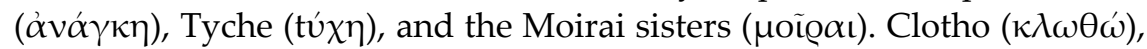
one of the sisters of Fate, was depicted with a spindle in her hand, aided by her sisters in the making of the yarn which symbolized the destiny of humans (Hesiod, Theogony 217, 904). This image was no mere story created to entertain the masses. Destiny, or necessity ( $\dot{\alpha} v \alpha \dot{\gamma} \gamma \uparrow)$, was the power 'on which all the revolutions turn', Plato said (Plato, Republic 10.616-617). In the Republic Plato inserts the same sentiment into a story abouts the soldier Er, who, after he is killed on the battlefield, ascends to encounter Fate. Er

\footnotetext{
2 This is a period at the beginning of which Rome gained dominance of the Mediterranean (from ca 30 BCE, when Egypt was conquered) until the time when the Roman emperors started to convert to Christianity. During this period Christianity became dominant, but at the end of it Jews, Christians, and Pagans - whether orthodox or heterodox, patrician or plebian - 'still breathed the same heavy air of a common civilization', as Peter Brown once put it in the influential work Late Antiquity: A Guide to the Postclassical World (Brown, Bowersock \& Grabar 1999, xi).
} 
observes Fate at work, weaving the human souls of the deceased into new bodies with new and different destinies (Republic 10.614-21). Plato's story of Er was based not only on myth but on the very scientific foundations of his time (Pollitt 1994; Buriks 1950).

Yet Fate was not depicted uniformly in antiquity. She often appeared as a goddess, as real as the other deities; however, just as often, she was portrayed in a more metaphorical sense, as the predisposition of a human being's lifespan. Fate appears as a power that Zeus used when confirming a certain plan of action. Nevertheless, what is clear is that once the wheels of Fate were in motion, one could not escape them - as long as one existed in a body consisting of matter, that is. Fate was closely associated with the orderliness and predictability of the cosmic system, the structure that defined human life, as it was understood in antiquity (Martin 1991, 151-69).

Fate was from the outset associated with the heavens and the motions of the planets, ${ }^{3}$ and as the Ptolemaic worldview became more firmly established, the circular movement of the spindle became an even more natural expression for the predictability of the ever-turning planets. Zeno called Fate 'a power in

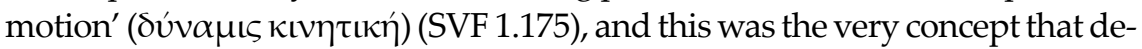
fined - indeed, named - the planets: the Greek word $\pi \lambda \alpha v \eta \dot{\tau}\rceil \varsigma_{\text {, ' }}$ wandering'. Fate turned the circular spindle of time and was thus intimately associated with the predictable and inescapable motions of the cosmos. The concept of Fate was not therefore used as a reference to something occurring without cause or by chance; Fate permeated the scientific worldview in Graeco-Roman society (Denzey Lewis 2013, Chapter 1). For the uninitiated and those who lacked all the facts and a cosmic perspective - that is, mortals and all those who were not omniscient sages - an accident or an untimely event might look like chance. But the cosmic system was closely interconnected, from the smallest piece of an atom to the motions of the planets. Humans, just like everything else in the cosmos, consisted of the four elements (five counting ether) associated with four different fluids (bile, blood, phlegm, and water), which generated four basic attributes (heat, cold, wet, dry). And Fate ruled them all, from the smallest animal and plant to the whole of humanity; as Herodotus said, not even Zeus himself could turn the wheels of destiny once they had been set (Herodotus, The Histories 1.19; Lactantius, The Divine Institutes 1.11, 1.13; Stobaeus, Eclogues 1.152, 1.170) (Pleše 2007, 237-68).

Just as the structure that held the predictability in order in the heavens was associated with a female power through the weaver Fate, so the most

3 Clotho's sister Lachesis is sometimes depicted as pointing to the horoscope on a globe, and Atropos with a sundial (Paus. 1.19). 
basic material attributes of human existence were associated with femininity. Women gave birth to the material body, and the sensations associated with the basic human drives like lust, hunger, and sleep were often named female emotions (or passions) (Knuuttila 2004). More often than not this was expressed in misogynic terms, a famous example being Aristotle's description of women as men who were not fully developed (On the Generation of Animals 728a13-27). Consequently, women fell prey to base emotions associated with the body more easily than men. The combination of Aristotelian natural speculations and the Ptolemaic worldview accorded the sublunary realm with feminine attributes, like dampness and cold. In short, the terrestrial realm was inseparable from femininity (Sambursky 1962).

It is far from surprising that the novel religious structures born in the context of the Mediterranean basin at the dawn of Hellenism - the mystery cults - often included a promise of concurring Fate. The deity, often a goddess to whom the cult was devoted, had found a way of controlling or escaping the restraints of a perpetual wandering, the image representing the circular motion controlling human life. Isis had long wandered about in search of her husband's dismembered body and fooled death by bringing Osiris back to life; Demeter, Orpheus, and Kybele were all powerful gods/goddesses engaged in sorrowful wandering and searching for dead loved ones (daughter/mate/mother) (Metamorphoses XI; Orphic Hymns 4, 7). Ultimately, they had all overcome the rule of Fate, and the mystery cults thus offered a release from the tireless wandering attached to materiality.

This context saw the birth of Christianity. As its dominance began to show and finally took over completely, the antique worldview ruled by Fate began to subside (Brown 1972). A world in which the spinning goddess was at the centre of time and causality gave way to one that would take human free will as self-evident. The power to choose one's own destiny was guaranteed by an almighty and good Father and his son, the Logos, who gave order to the world. However, this transition - which, in light of the above depiction of the world of Fate, must sound like a shift between two totally opposing worldviews - did not happen overnight. For centuries Christianity debated the nature of human will, as well as the role the female principles associated with the governance of the cosmos and the human body should have (Linjamaa 2019). The following will be devoted to exploring Christian attitudes to Fate and will trace the process that finally led to her rejection. As I will argue, she was not simply denied but was instead replaced slowly with other feminine religious symbols, as well as the introduction of a new view of the self. 


\section{Providence and the reception of Fate in early Christianity ${ }^{4}$}

No obvious female principles or a Fate goddess were mentioned in the Genesis creation story. Nevertheless, as Fate played a central role in the most current scientific worldviews of the time, Jewish and Christian intellectuals were prone to integrate Fate - at least for a time - in their particular cosmologies (Miller 2016).

Christians and Jews developed their own take on Fate, and this was partly done by developing the image of Providence (ז@óvot $\alpha$ ) (Frick 1999; Bergjan 2002; Miller 2016). Apart from Fate, in several of his writings Plato had mentioned another female figure associated with the foundations of cosmic life, a world soul which the Demiurge had created. This world soul defined what it meant to be made up of a substance spatially and temporally bound to Fate (Laws 10.896a; Timaeus 35a, 37a-c, 34c; Phaedrus 246b-c). It was this concept that would influence Stoics and Middle Platonic thinkers, as well as Christian and Jewish writers, to develop notions concerning a female principle called Providence ( $\pi$ @óvot $\alpha$ ) around the second century CE. Providence was closely associated with Fate, but she retained a more elevated position (Apuleius, De Platone er eius dogmate; Pseudo-Plutarch, De Fato). While Fate was associated with the sublunary spheres, as well as the bodies of and the passions stirring within humans, Providence was associated with the creation and governance of the highest realms (Apuleius, De Platone er eius dogmate 1.12; Denzey Lewis 2013).

Pseudo-Plutarch and Apuleius separated Providence and Fate. The highest Providence had Fate inside it, according to Psuedo-Plutarch, and was the primary God's wholly beneficial will. Middle Providence and Fate acted between the highest plane and the cosmos, while lower Providence was included in Fate and acted with the daimons in the cosmos, the 'lower gods', as Plato called them in Timaeus. These lower powers could induce irrational passions within humans (Pseudo-Plutarch, De Fato 572f-574b; Plato, Timaeus $42 \mathrm{~d}-\mathrm{e}$ ). Apuleius viewed Fate and Providence as corresponding. He divided Providence into three parts, where Fate was a lower aspect of Providence. Notions of higher and lower forms of Providence developed too, the lower one often directly identified with Fate (Apuleius, De Platone er eius dogmate).

Among Jews and Christians Providence was considered the personifica-

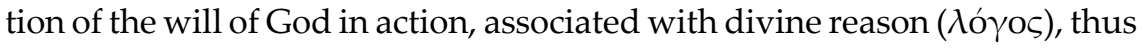
representing God's benevolent will in the universe (Miller 2016; Frick 1999).

4 I have written about the topic in the beginning of this section, in much the same manner, in Linjamaa 2016. 
Clement of Alexandria, for example, wrote that the true ruler and director of the world was the Word of God and his Providence ( $\pi$ @óvor $\alpha$ ), and that by the will of the Almighty the Son had taken flesh so humans might see and handle him (Stromata VII.2:8). According to Philo, whose ideas would influence many Christians, God was the father of all rational creatures and exercised his Providence ( $\pi$ @óvot $\alpha$ ) for the protection even of those who sinned against him (On the Embassy to Gaius 24.3, 25.1-27.2).

As Middle Platonist thinkers had done, Christian authors also experimented with dividing Fate and Providence into higher and lower forms to distance the will of God (most often considered benevolent) from the more deprived aspects of cosmic life, such as the baser drives of the human body and low passions (Frick 1999; Williams 1992; Perkins 1980). Athenagoras of Athens, for example, wrote that it was through a lower form of Providence that malevolent angels stirred up 'irrational movements' in humans, causing them to act on passions which drew them away from God.

Some Christians associated Fate and Providence with Wisdom (המכח/ $\sigma o \varphi(i)$, the creative power of God mentioned in the Jewish Scriptures (Psalms 104:24; Proverbs 8:22-31), a character that was at times personified. In the Apocryphon of John, a very popular second-century Christian text that was heavily inspired by Platonism and allegorical readings of Genesis, the cosmos is a tragedy occasioned by the fall of Wisdom from heaven. She gives birth to a creator god, who, along with his base angels, controls humans through Fate. In the Apocryphon of John, Fate is closely connected with

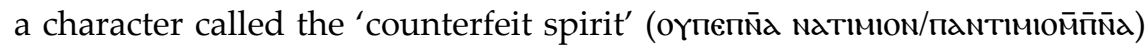
(BG 73) (Pleše 2007). However, the benevolent Providence governed with Wisdom in a higher realm, and it was by imitating her that the evil angels found inspiration when creating Fate and the 'counterfeit spirit' associated with her (BG 73). While Fate and the evil counterfeit spirit enslave people through introducing sexual lust and the need to procreate, Providence plays a salvific role in the Apocryphon of John. Fate was more often than not represented as a negative character; Providence was her opposite, portrayed as a saving force in many early Christian texts. But even Providence was at times drawn down by the negative connotations of Fate. In a Christian text associated with the Apocryphon of John called On the Origin of the World, we encounter a malevolent lower form of Providence which is responsible for introducing sexual desire and corporeality, subjected to Fate (Denzey Lewis 2013, 37ff.) This is just one example of the fact that the role of Providence and Fate in relation to God and the structures of the cosmos was anything but firmly established among early Christians. 
In some other early Christian texts - for example, in the third-century work The Interpretation of Knowledge - Wisdom is divided in the same way as the providential powers. The lower Sophia used Fate as a tool to restrict humans, while the higher form retained her place in heaven with God. ${ }^{5}$

Just as in Graeco-Roman culture in general, the early Christians appropriated the view of Fate and femaleness as being typically associated with materiality and the circular motions that life in the cosmos entailed. ${ }^{6}$ In one third-century text, The Tripartite Tractate, we read that people should strive to avoid being coerced by material life, because it was a 'sickness...

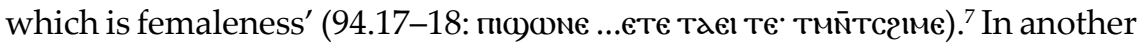
third-century Christian text, Excerpta ex Theodoto, quoted by Clement of Alexandria, this is put in still more emphatic terms:

Now he says that he means by flesh that weakness which was an offshoot of the Woman on high... On her account the Savior came down to drag us out from passion and to adopt us to himself. For as long as we were children of the Female only as if of a base intercourse, incomplete and infants and senseless and weak and without form, brought forth like abortions, we were children of the Woman.

Fate is a union of many opposing forces and they are invisible and unseen, guiding the course of the stars and governing through them. For as each of them arrived, borne round by the movement of the world, it obtained power over those who were born at that very moment, as though they were its own children. Therefore, through the fixed stars and the planets, the invisible powers hold sway over them direct and watch over births. Until baptism, they say, Fate is real... So long, they say, as the seed is yet unformed it is the offspring of the Female, but when it was formed, it was

5 Linjamaa 2016, 29-54. For more see Irenaeus's depiction of a similar system in Against Heresies 1.4. The lower form of Wisdom (also called Achamoth/Wisdom) resembles the Platonic World Soul and the 'receptacle' in that she is accountable for, and associated with, the elements that make up the cosmos and the human limitations within it. However, the Higher Wisdom remains with the Pleroma, and the Wisdom of the highest Father is thus partly spared the humiliations of passion and the disturbing parts of the corporeal realm.

6 The misogynic implications of this have been studied by April DeConick (2011), although I have previously argued that the conclusion she reaches that the 'Gnostic' traditions differed from proto-orthodoxy by promoting a more friendly theology with regard to women is unlikely (Linjamaa 2019, 108-109; Linjamaa 2021).

7 In The Interpretation of Knowledge the feminine cosmic life under the sway of Fate is defined as a constant 'toil' (ટા૮૯). This Coptic word, ટાલ€, means work, toil, trouble, suffering, but it can also mean to spin (Crum 1939, §713; Smith 1983, 51). Spinning, as in spinning cloth or the spinning of the planetary spheres, symbolized human life on earth. 
changed into a human and becomes a son of the bridegroom. (Transl. Pierce Casey 1934)

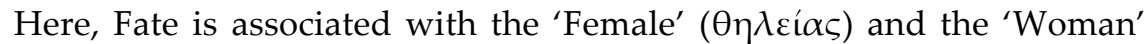
( $\gamma \cup v \alpha \iota \kappa \varepsilon \tilde{\imath} 0 v)$ who brings flesh into existence. The human is likened to a seed $(\sigma \pi \varepsilon \dot{\varepsilon} \mu \alpha)$ which the Female controls through the movements of the cosmos. The birth of the Saviour and baptism is said to have 'released us from becoming and Fate' (76:1). ${ }^{8}$ As in the mystery cults, initiation and protection by a divine figure who had mastered death gave protection from Fate and the everchanging existence in the cosmos (Martin 1987, 21-6, 41-5, 82f., 157-60).

Above, we see how many early Christians adopted much the same views that permeated the antique world concerning the symbol of femaleness and its association with the governance of material life in the cosmos. Fate was a powerful cosmic force that could not be ignored (Martin 1987). Human action, will, and the causality of the world were interlinked and inseparable from Fate. The divine cause, law, or prime mover behind all existence was by many (if not most) thought to be benevolent; what took place on earth was according to the best of plans. ${ }^{9}$ This had to be squared with the baseness of some aspects of material life, like death and suffering. Speculations about Providence, Fate, Wisdom, and other powerful female cosmic forces were attempts to address this inconsistency, by distancing the highest law/god from these evils. Christians also speculated concerning this, but the forms of Christianity that ultimately came to dominate the religious scene from the fall of the Roman Empire and beyond would resolve the question of evil in another way (Scott 2012). What was decided to be required doctrine at the great Church Councils, beginning with Nicaea in 325, would deny the existence of Fate. The Wisdom of God and Providence were still acknowledged but were not viewed as separate entities from God; they were indistinguishable extensions of God himself. Fate was rejected outright. This view became the norm and has recently been rearticulated by Pope Francis himself:

The Christian does not believe in an ineluctable 'Fate.' There is nothing haphazard in the faith of Christians. There is, instead, a salvation that awaits manifestation in the life of every man and woman, and fulfilment in eternity. If we pray it is because we believe that God can and wants to transform

8 This is a reference to what looks to be the Platonic concepts of Becoming. Becoming was the cosmic copy of the eternal Being, infringed by time, materiality, and perpetual change: an existence in motion (Plato, Timaeus 2dff).

9 Of course, there are exceptions to this rule - for example, the Epicureans. 
reality by overcoming evil with good. To this God it makes sense to obey and abandon oneself even in the hour of greatest difficulty. (Hattrup 2019.)

How did the simple rejection of the existence of Fate become a core Cristian doctrine when so many early Christians struggled so hard to overcome her influence in other ways, as Middle Platonists and other philosophers had done?

\section{The Christian invention of human autonomy: new weavers appear}

The philosophical schools in antiquity did not accept the idea that humans were endowed with free will; it was considered quite implausible (SVF 1:176; 2:1118; 2:913; 2:937; 2:933; Diels 1961, 324a4; Denzey Lewis 2013, 89-91). People acted against their own benefit all the time, which was something they would not do if their free will was not controlled by some false beliefs or passions. This was how free will was understood in antiquity, before the advent of Christianity. While some Christians attacked the question of evil and human weakness with complex doctrines of Fate and Providence, others like Justin Martyr, Irenaeus, Tatian, and Origen applied a straightforward doctrine of free will (Origen, On First Principles I.8.1-2, II.1.1, II.6.3-6, II.8.3-4, II.9.1-6; Justin, First Apology 43; Irenaeus, Against Heresies IV.37, 39; Tatian, Address to the Greeks 7.1; Clement, Stromata II.5.26.3, V1.7.1-2).

It is here, among certain early Christian theologians, where we first encounter a doctrine stating that humans are endowed with a divinely given free will to choose between good and evil in every given situation. The doctrine did not lend itself easily to the complex ontological or epistemological questions attached to the nature of human decision making, but it did resolve the difficulty of imagining a just and caring God in charge of a world full of suffering. What had often been attributed to Fate was viewed as the result of the actions taken by free individuals. If one fell victim to unexplainable events like disease or accident, they were probably the results of the influence of demons and foul angels who, ${ }^{10}$ just like humans, had been attributed with a free will of their own, and just like humans, would be judged for their actions in the end time (Karamanolis 2014; Frede 2011).

While some, as we have seen, tried to mitigate the influence of Fate by downgrading her to the lower position in a hierarchy of providential goddesses, others simply rejected her existence. We see an example of this in

10 Thus, the production of protective amulets and spells warding off malicious spirits associated with the body did not subside with the dawn of the Christian doctrine of free will. 
the writings of Methodius of Olympus, who stated in his text Banquet of the Ten Virgins ${ }^{11}$ - from the end of the third century, possibly the beginning of the fourth - that the thought that one could blame one's sins on Fate was pure insolence:

...of all evils the greatest which is implanted in many is that which refers the causes of sins to the motions of the stars, and says that our life is guided by the necessities of Fate, as those say who study the stars, with much insolence (Banquet of the Ten Virgins 8.13, Transl. Clark 1886).

Later influential theologians, like Gregory of Nyssa and Augustine, were of a similar opinion to Methodius (Augustine, City of God 5.1; Gregory of Nyssa, Contra Fatum) (Scott 2012). The popularity of the doctrine of free will thus had ramifications for the views held within Christian systems, which favoured cosmologies and theories of the mind that included Fate and Providence. In Methodius's writings we find another revealing example, this time of how Fate was not simply denied but replaced by another female figure:

Now she who brings forth, and has brought forth, the masculine Word in the hearts of the faithful, and who passed, undefiled and uninjured by the wrath of the beast, into the wilderness, is, as we have explained, our mother the Church. And the wilderness into which she comes, and is nourished for a thousand two hundred and sixty days, which is truly waste and unfruitful of evils, and barren of corruption, and difficult of access and of transit to the multitude; but fruitful and abounding in pasture, and blooming and easy of access to the holy, and full of wisdom, and productive of life, is this most lovely, and beautifully wooded and well-watered abode of Arete. (8.11) (Transl. Clark 1886)

Methodius goes on to critique the ideas of astral determinism and the notions of Fate. Methodius rejects Fate - the idea of a powerful Providential goddess is not mentioned - and instead we find Mother Church. The image

11 Banquet of the Ten Virgins, which became immensely popular in medieval times in literature and art, centred on a parable found in Matthew 25:1-13 about ten torch-bearing virgins who awaited the arrival of a bridegroom for a wedding feast. Five virgins came carrying lamps with oil, while the other five brought lamps with insufficient oil and had to leave in search of more. Thus, they missed the coming of the bridegroom and the wedding. Methodius connected the doctrine of Fate with erroneous doctrines one had to abandon so as not to miss the feast of the end time. Instead of giving into the idea of the goddess of Fate, one should follow the lead of another female power. 
of the Church as a mother has been studied thoroughly before (Plumbe 1943; Lubac 1983), but the connection with past female images - not to mention Fate - is seldom discussed. If people chose to follow Mother Church, the bride of Christ, she would give them access to the feasts of the end time (8:11). In Methodius's words, she is placed on earth by the Father to fight the corruption in which some people chose to engage, and through her and her bridegroom Christ people were offered the bounty of eternal life. One female figure (Fate/Providence) is here replaced by another (the Church).

As the doctrine of free will developed and finally became established as orthodoxy within the growing and more centralized church, the need for complex theories of female cosmic principles like Fate and Providence began to subside. Mother Church was not the only female principle that mitigated the loss of powerful female principles attached to the basic structures of life. Eve, the originator of all humans (Anderson 2001), and Mary, the mother of God, were potent female figures, ${ }^{12}$ but docile compared with Fate/Providence. ${ }^{13}$ Let us end by placing the above survey of this shift in femininities in the light of another historical transformation which occurred at the same time as the one that has hitherto engaged us, one that has been discussed by many famous historians and intellectuals: the birth of a new view of the self in late antiquity.

\section{Rejecting Fate: a new liable 'technology of the self' is born}

During the high and late Roman Empire, a new and internalized morality takes form as Christianity wins dominance, a theme studied by many famous historians. During the nineteenth and much of the twentieth century the leading paradigm of this shift was the formulation of the influential classicist E. R. Dodds. Dodds argued that people in the high and late Roman period, and until late antiquity, were troubled by a pressing feeling of alienation, an anxiety caused by the fear of Fate and the feeling of smallness

12 In the second-century Protoevangelion of James Mary is in charge of the thread of the most precious colour, purple, when a group of virgins are put to the task of weaving the veil of the temple, which separates the world from the divine. In the Gospel of Pseudo-Matthew Mary spends her time spinning and working with wool when she is not in prayer (Nicholas 1995, 169-94; Gines 2018).

13 It is hardly an accident that Mary is closely tied to the typical act of femaleness: weaving. Mary is the one who weaves Logos's body; she is the Father's rational principle at work in the world. Like the women in Exodus 35:26 weaving the Tabernacle, Mary brings forth the container for the representation of the divine in the world. Similarly, humans are introduced to a life in the body at birth but are no longer tied to a certain Fate by the weaver, but to a fate determined by themselves. 
and insignificance triggered by the growing knowledge of the vastness of the universe. These feelings subsided, Dodds argued, as Christianity began to spread, supplanting anxiety with a feeling of awe for the infinite that the idea of a pending immortal life gave people (Dodds 1965). Dodds's model was broadly accepted and supported by many prominent historians like Franz Cumont, Arthur Darby Nock, André-Jean Festugiere, and Hans Jonas (Denzey Lewis 2013, 184).

In the later work of Michel Foucault we find a very different version of the changes taking place during the later parts of antiquity. In Foucault's History of Sexuality he discusses the changes that occurred in the view of the self and sexuality with the dawn of Christianity:

The Greeks problematized their freedom, and the freedom of the individual, as an ethical problem. But ethical in the sense in which the Greeks understood it: èthos was a way of being and of behavior. It was a mode of being for the subject, along with a certain way of acting, a way visible to others. A person's èthos was evident in his clothing, appearance, gait, in the calm with which he responded to every event, and so on. For the Greeks, this was the concrete form of freedom; this was the way they problematized their freedom. A man possessed of a splendid èthos, who could be admired and put forward as an example, was someone who practiced freedom in a certain way. (...) But extensive work by the self on the self is required for this practice of freedom to take shape in an êthos that is good, beautiful, honorable, estimable, memorable, and exemplary. (Foucault 1996 [1984]), 436)

The ideal was to master the will completely, a task for which only philosophers had the inclination to strive. Yet as was obvious from outward appearance, most people never got that far. Foucault's unfinished fourth volume of the History of Sexuality was recently published posthumously (Foucault 2018), and here he continues his examination. In his analysis of the new Christian attitudes forwarded by the early church fathers, a new morality and view of the self enabled people to engage in constant self-regulation and scrutiny of the self to ascertain that they had not fallen victim to desire and sin. One was no longer measured outwardly by others, but inwardly by oneself. The act of confession was the prime example of this, when one scrutinized and confessed one's failures. Sexual desire was an impulse that caused great distress, because it was the sign of other and graver failings. Christians were expected to lead 'a life not of this world' ('une vie qui n'est pas de ce monde', Foucault 2018, 234). 
Dodds's paradigm about the feeling of anxiety governing people has all but been abandoned today, due largely to the very influential work of Peter Brown. As it happens, Foucault's notions are echoed in much of Brown's works on the changes taking place in the late ancient world. As Brown and Foucault both observe, moral perfection had been closely associated with excellence and absolute rationality. Most people lacked the inclination or possibility to devote their life to developing their intellect. Nor was it expected of people. One should play the part one had been given by Fate to the best of one's ability. As Plato and Aristotle had made clear, a functional society needed all classes of people. As such, there was one ethics for the public and one for those who strove for moral excellence. The Christian morality that would prevail was something different. Brown's works on the view of how the image of the philosopher is taken over by the Christian monk, and how the view of the human body and sexuality are transformed in late antiquity, confirm this (Brown 1988).

At the same time one cannot deny that the role of Fate subsided with the dawn of Christianity, as Dodds discusses. As we have seen in the above study, it was finally supplanted by the notion of human free will, which was a non-existent notion in antiquity prior to Christianity. This undoubtably had consequences for the view of the self. If we add the perspective of the diminishing importance of the goddess Fate and the birth of the notion of free will discussed in this article, I argue that we stand to gain yet another dimension to the work done on tracing the changes in the view of selfhood in antiquity.

Brown is right that it cannot have been anxiety about the rule of Fate that drove the changes in selfhood discussed and developed by Foucault. In one way the Christian worldview that was to prevail posited an even more daunting premise, because the access to complete freedom made every individual liable to shape themselves into a virtuous person who deserved salvation or doom. As Brown and Foucault have pointed out, the domain which had previously been restricted to the realm of philosophers - seeking moral excellence - was in one sense popularized, and I would contend that the supplanting of Fate by free will played a role in this (Brown 1988; Foucault 2004). This change did not merely affect how the 'technology of the self' was conducted, in Foucault's terms; it was the very premise of such a technology. A world in which Fate had given each person their particular role to play did not allow for transformations of this new kind. The focus among the population at large no longer lay on strengthening the self externally to become as effective as possible in the world, but rather 
on self-examination, confession, and transformation to gain access to the life after (Foucault 2004). Guy Stroumsa has emphasized this latter part, and also points to the new importance placed on the written word and the invention of the codex (Stroumsa 2009). Blood sacrifice was given up and replaced by an internal sacrifice in the form of the spoken word, which was uttered both internally and externally to symbolize the transformation one pledged to undertake.

The new ideal of virginity which becomes prevalent in Christianity, explored by Brown, is an expression of the lengths to which the introduction of a powerful human will could reach. The will, which in antiquity chiefly restricted attitudes and appearances in the mind, was extended to a system that was also to control the body and sexuality (Brown 1985, 427-43). As we have seen, many Christians tried to attribute the problems of the baseness of the human body to various aspects of Fate and Providence that lay outside the human and could be overcome. This attempt was finally abandoned as free will prevailed, and it thus became a chiefly internal affair. Choosing virginity was the ultimate testament of a free will directed towards virtue.

But perhaps most acutely, the structure presented by an ever-present Fate in the sky lends itself to the nature of the ancient discourses of power. The ultimate expression of power - violence - was ever present in antiquity. As Brown puts it: 'wives and slaves in the household to the abject courtiers of tyrannical rulers, the lives of so many persons in so many situations appeared to depend on the whim of their superiors' (Brown 1992, 50). This exercise of power was felt at all levels of Roman society. The short period between the third and fourth centuries CE saw nearly thirty emperors and countless contenders come and go, many of whom died violent deaths. The power discourse had an arbitrariness that would easily have been explained by reference to the whims of Fate. The dawn of Christianity in no way changed the seemingly arbitrariness of the application of power - considering the flood of Germanic tribes into the western parts of the empire, it could even be viewed as yet more capricious - but Fate's exit was slowly supplanted by the equally distant will of God. Power was given by God, and the ways of God were unfathomable. However, one was free to change the course of one's own eternal destiny by forming oneself and turning one's will not outwardly towards the world, but towards oneself. 


\section{Conclusion}

This article has explored how the notion of Fate and Providence subsided during the high and late Roman period. As we have seen, the Christian worldview which won prominence was slowly formed, giving way to a worldview without the presence of powerful female cosmic principles. The disappearance of these powerful female symbols coincided with the birth of new ideals in which the individual was responsible for his/her own salvation and moral formation. It was not just Fate that disappeared, but the divine female active force - like Isis, Kybele, and Wisdom. This female force had offered concrete protection against the tribulations of material life and gave way to other female characters like Mother Church that offered people moral tools to be turned inwards. The transformations that occurred during this period extend to the realm of power, the view of the human body, and ethics, exemplified by a new focus on self-governance. A fruitful way to begin to approach these monumental transformations taking place in the latter parts of antiquity is through the above discussion regarding the supplanting of Fate in favour of free will.

PAUL LINJAMAA is Docent of History of Religion at the Centre for Theology and Religious Studies, Lund University. E-mail: paul.linjamaa@ctr.lu.se 
Bibliography

Primary Sources

\section{Apuleius}

De Platone er eius dogmate. - Ryan C Fowler (ed), Imperial Plato: Albinus, Maximus, Apuleius: Text and Translation, With an Introduction and Commentary. Las Vegas: Parmenides Publishing, 2016.

\section{Augustine}

City of God. - William Green, Augustine: City of God, Volume II: Books 4-7. Loeb Classical Library 412. Cambridge M.A.: Harvard University Press, 1962.

\section{Aristotle}

On the Generation of Animals. - Arthur L. Peck (ed.), Aristotle: On the Generation of Animals. Loeb Classical Library 366. Cambridge M.A.: Harvard University Press, 1942.

\section{BG}

Berlin Codex (BG 8502,2). - Michael Waldstein \& Fredrik Wisse (ed.), The Apocryphon of John: Synopsis of Nag Hammadi Codices II, 1; III,1; and IV,1 with BG 8502,2. Leiden: Brill, 1995.

\section{Clement of Alexandria}

Stromata. - William Wilson (ed), The Ante-Nicene Fathers, vol. 2, eds. Alexander Roberts et al. Grand Rapids: Eerdmans, 1979.

\section{Excerpta ex Theodoto}

Robert Pierce Casey (ed.), Excerpta ex Theodoto of Clement of Alexandria. Cambridge, MA: Harvard University Press, 1934.

\section{Gregory of Nyssa}

De Fatum. - James Andrew McDonough (ed), The Treatise of Gregory of Nyssa Contra Fatum. Cambride, MA: Harvard University Press, 1952.

\section{Herodotus}

The Histories. - Nigel Wilson (ed), Herodoti Historiae: Libri I-IV: 1-4. Oxford: Oxford University Press, 2015.

\section{Hesiod}

Theogony. - Glenn W. Most (ed), Hesiod: Works and Days. Testimonia. Loeb Classical Library 57. Cambridge M.A.: Harvard University Press, 2018.

\section{Irenaeus}

Against Heresies. - Dominic J. Unger, Against the Heresies Book 1 . New York: The Newman Press, 1991. 


\section{Justin Martyr}

First Apology. - Leslie William Barnard (ed), Justin: First and Second Apology. New York: Paulist Press, 1997.

\section{Lactantius}

The Divine Institutes. - Mary Francis McDonald (ed), The Divine Institutes: Books I-VII. Washington, D.C.: Catholic University of America Press, 1964.

\section{Methodius}

Banquet of the Ten Virgins. - Clark, William R. (ed.), Ante-Nicene Fathers. Buffalo, NY: Christian Literature Publishing Co, 1886.

\section{Origen}

On First Principles. - G. W. Butterworth (ed), Origen: On First Principles. Notre Dame: Christian Classics, 2013.

\section{Orphic Hymns}

Thomas Taylor \& Manly P. Hall (eds.), The Hymns of Orpheus. Los Angeles: Philosophical Research Society, 1987.

\section{Ovid}

Metamorphoses. - Frank Justus Miller (ed), Ovid: Metamorphoses. Loeb Classical Library 42. Cambridge M.A.: Harvard University Press, 1916.

\section{Philo}

On the Embassy to Gaius. - Francis H. Colson (ed), Philo: On the Embassy to Gaius. Loeb Classical Library 379. Cambridge M.A.: Harvard University Press, 1962.

\section{Plato}

Republic. - Paul Shorey (ed), Plato: Republic. BookIV-X. Loeb Classical Library 276. Cambridge, MA: Harvard University Press, 1935.

Timaeus. - Robert Gregg Bury (ed), Plato: Timaeus, Critias, Cleitophon, Menexenus, Epistle. Loeb Classical Library 234. Cambridge, MA: Harvard University Press, 1929.

\section{Pseudo-Plutarch}

De Fato. - Phillip H. De Lacy \& Benedict Einarson, Plutarch: Moralia, vol. 7. Loeb Classical Library 405. Cambridge M.A.: Harvard University Press, 1959.

\section{Stobaeus}

Eclogues. - Curtius Wachsmuth \& Otto Hense, Ioannis Stobaei Anthologium, Volume 1, Berlin: Weidmannsche Buchhandlung, 1894.

\section{SVF}

Stoicorum Veterum Fragmenta. - Hans von Arnim (ed). Berlin: de Gruyter, 2004. 


\section{Tatian}

Address to the Greeks. - J. E. Ryland (ed), Tatian: Address to the Greeks. AnteNicene Fathers, vol. 2, eds. Alexander Roberts et al. Buffalo, NY: Christian Literature Publishing Co., 1885.

The Tripartite Tractate

Nag Hammadi Codex I. - Harold W. Attridge (ed). Leiden: Brill, 1985.

Secondary Sources

Anderson, Gary A.

2001 The Genesis of Perfection: Adam and Eve in Jewish and Christian Imagination. Louisville \& London: Westminster John Knox Press.

\section{Bergjan, Silke-Petra}

2002 Der fürsorgende Gott: der Begriff der PRONOIA Gottes in der apologetischen Literatur der Alten Kirche. Berlin: de Gruyter.

\section{Brown, Peter}

1972 Religion and Society in the Age of Saint Augustine. London: Harper \& Row.

1985 The Notion of Virginity in the Early Church. - Bernard McGinn \& John Meyendorff (eds), Christian Spirituality: Origins to the Twelfth Century, 427-443. New York: Crossroad.

1988 The Body and Society: Men, Women and Sexual Renunciation in Early Christianity. Boston \& London: Faber and Faber.

1992 Power and Persuasion in Late Antiquity. Madison: The University of Wisconsin Press.

Brown, Peter, G. W. Bowersock \& Oleg Grabar (eds)

1999 Late Antiquity: A Guide to the Postclassical World. Cambridge, MA: Belknap Press of Harvard University Press.

\section{Buriks, Agatha A.}

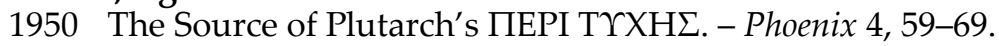

\section{Christ, Carol P.}

1997 Weaving the Fabric of Our Lives. - Journal of Feminist Study in Religion $13,131-36$.

\section{Crum, Walter}

1939 A Coptic Dictionary. Oxford: Clarendon Press. 


\section{DeConick, April}

2011 Holy Misogyny: Why the Sex and Gender Conflicts in the Early Church Still Matter. New York: Bloomsbury.

\section{Denzey Lewis, Nicola}

2013 Cosmology and Fate in Gnosticism and Graeco-Roman Antiquity. Leiden: Brill

Diels, Herman Alexander

1961 Doxographi gracei. Padua: EDAM.

\section{Dodds, Eric Robertson}

1951 Greeks and the Irrational. Berkeley: University of California Press.

1965 Pagan and Christian in an Age of Anxiety. Cambridge: Cambridge University Press.

\section{Eidinow, Esther}

2011 Luck, Fate and Fortune: Antiquity and its Lega. New York: Oxford University Press.

\section{Frede, Michael}

2011 A Free Will: Origins of the Notion in Ancient Thought, ed. A. A. Long. Berkley: University of California Press.

\section{Frick, Peter}

1999 Divine Providence in Philo of Alexandria. Tübingen: Mohr Siebeck.

\section{Foucault, Michel}

2004 The Hermeneutics of the Subject: Lecurese at the Collége de France 1981-1982, ed. Frédéric Gros, transl. by Graham Burchell. New York: Palgrave Macmillan.

2018 Histoire de la sexualité 4: Les aveux de la chair, ed. Frédéric Gros. Paris: Gallimard.

1996 [1984] The Ethics of the Concern for the Self. - Sylvère Lotringer (ed), Foucault Live (Interviews, 1961-1984), 432-449. Los Angeles: Semiotext(e).

\section{Gines Taylor, Catherine}

2018 Late Antique Images of the Virgin Annunciate Spinning: Allotting the Scarlet and the Purple. Leiden: Brill.

\section{Hattrup, Kathleen N.}

2019 Why Christians don't believe in Fate: Pope explains. - Aleteia, 20 March.

\section{Karamanolis, George E.}

2014 The Philosophy of Early Christianity. London and New York: Routledge. 


\section{Knuuttila, Simo}

2004 Emotions in Ancient and Medieval Philosophy. Oxford: Clarendon Press.

\section{Krawiec, Rebecca}

2002 Shenoute and the Women of the White Monastery. Oxford: Oxford University Press.

\section{Linjamaa, Paul}

2016 The Female Figures and Fate in The Interpretation of Knowledge, NHC XI,1. - Journal of Early Christian Studies 24, 29-54.

2019 The Ethics of The Tripartite Tractate: Determinism and Early Christian Philosophy of Ethics. Leiden: Brill.

2021 Receptions of Pistis Wisdom and Gnosticism: From Esoteric Milieus in Nineteenth- and Early Twentieth-Century Europe to Contemporary Academia. - Aries 22: forthcoming, August 2021.

\section{Lubac, Henri de}

1983 The Motherhood of the Church. San Francisco: Ignatius Press.

\section{Martin, Luther}

1987 Hellenistic Religions. Oxford: Oxford University Press.

1991 Fate, Futurity and Historical Consciousness in Western Antiquity. Historical Reflections/Réflexions Historiques 17, 151-69.

\section{Miller, Richard W.}

2016 Abraham's Dice: Chance and Providence in the Monotheistic Traditions. Oxford: Oxford University Press.

\section{Nicholas, Constas P.}

1995 Weaving the Body of God: Proclus of Constantinople, the Theotokos, and the Loom of the Flesh. - Journal of Early Christian Studies 3, 169-94.

\section{Perkins, Pheme}

1980 On the Origin of the World (CG II, 5): A Gnostic Physics. - Vigiliae Christianae 34, 36-46.

\section{Pleše, Zlatko}

2007 Fate, Providence and Astrology in Gnosticism. - MHNH: Revista Internacional de Investigación sobre Magia y Astrología Antiguas 7, 237-68.

\section{Plumbe, Joseph C.}

1943 Mater Ecclesia: An Inquiry into the Concept of the Church as Mother in Early Christianity. Washington: Catholic University of America Press.

\section{Pollitt, Jerome Jordan}

1994 An Obsession with Fortune. - Susan B. Matheson (ed), An Obsession with Fortune: Tyche in Greek and Roman Art, 12-17. New Haven: Yale University Art Gallery. 


\section{Sambursky, Samuel}

1962 The Physical World of Late Antiquity. New York: Basic Books.

Scott, Mark

2012 Journey Back to God: Origen on the Problem of Evil. Oxford: Oxford University Press.

Smith, Richard

1983 A Concise Coptic-English Lexicon. Second Edition. Atlanta, GA: Society of Biblical Literature, Scholars Press.

\section{Stroumsa, Guy}

2009 The End of Sacrifice: Religious Transformations in Late Antiquity. Transl. by Susan Emanuel. Chicago: University of Chicago Press.

\section{Williams, Michael A.}

1992 Higher Providence, Lower Providence and Fate in Gnosticism and Middle Platonism. - Rich T. Wallis (ed), Neoplatonism and Gnosticism, 483-507. Albany: New York State University Press. 
